\title{
INTERTEXTUALITY AND THE USE OF SCRIPTURE IN THE BOOK OF REVELATION? ${ }^{1}$
}

\author{
Steve Moyise \\ University College \\ United Kingdom
}

\begin{abstract}
In an article in 1993 and a monograph in 1995, I used the literary concept of intertextuality to describe the complex use of the Old Testament in the book of Revelation. In this article, I review seven recent monographs (Ronald Farmer, Robert Royalty, Gregory Beale, Alison Jack, Sverre Bøe, Pilchin Lee, David Mathewson) and an important article by Paul Decock to determine whether intertextuality has proven to be a useful concept for understanding John's use of Scripture.
\end{abstract}

\section{Introduction}

When I began my work on John's use of Scripture, it seemed to me that previous work fell largely into two camps. First, there were those who were primarily impressed by continuity, respect for context and a proper use of typology. I think particularly of Beale's work, with his argument that certain chapters of Revelation $(1,4-5,13$ and 17) are a midrash on Daniel 7 and that the presence of $\ddot{\alpha} \delta \in \hat{\imath} \gamma \in \nu^{\prime} \in \sigma \theta \alpha \iota$ (from Dan 2:28) in Rev 1:1, 1:19 (modified), 4:1 and 22:6 implies that the "contents of the whole book are to be conceived of ultimately within the thematic framework of Daniel 2" (1984: 277). I also think of Fekkes, and his argument that when John uses Isaiah, he uses visionary descriptions for visionary descriptions, oracles against the nations for descriptions of Babylon, oracles of salvation for descriptions of eschatological renewal and visions of the restoration of Zion for his description of the New Jerusalem. Fekkes claims that there are very few instances where John strays from the "obvious" meaning of Isaiah (1994: 287) and that he fully expected his readers to "appreciate the exegetical foundation of his visions" (1994: 290)

On the other hand, there are those like Vos (1965) and Vogelgesang (1985) who argue for a considerable amount of discontinuity, a lack of respect for context and an improper use of typology. Thus Vos points out that John's visionary descriptions of the "one like a son of man" in Revelation 1 and the great angel in Revelation 18 gather up a number of evocative phrases, regardless of whether they were previously descriptions of God, angels or human beings (1965: 21-37). And Vogelgesang thinks that John follows the order of Ezekiel to a major extent but deliberately changes key features in order to "democratize" its message. According to Vogelgesang, the parallelism between Revelation 17-18 and 21-22 shows that John's vision of the new Jerusalem represents "Babylon redeemed", "an absolutely unthinkable possibility given the original intentions of Ezekiel 40-48” (1985:113).

\section{The contribution of intertextuality}

As for my own studies, I felt the truth lay somewhere in between; that one somehow has to do justice to both continuity and discontinuity. And for this I looked to notions of intertextuality that were just entering biblical studies in 1989. Drawing on the theories of

1. An expansion of a paper given at NTSSA (Potchefstroom), April 2002. 
Kristeva (1986), Hollander (1981) and Greene (1982), I attempted to formulate a position where the meaning of John's use of Scripture lies in the tension between its previous contextual definition(s) and the new context supplied by John (Moyise,1995: 138). The Old context does not determine John's meaning because the text has been set free from its previous textual moorings and now exists in a new context. However, neither is it true that John can make texts mean whatever he likes, for the old text brings with it connotations and associations that influence the new setting. Thus there is a dynamic whereby the new affects the old and the old affects the new, leading to two important tasks: (1)To find ways of describing such a dynamic interaction; and (2)To consider the effect this has on the reader. Two examples will illustrate the point.

\subsection{The lion and the lamb}

In 1989, it was practically a consensus among Christian commentators that John reinterprets the messianic warrior lion with the sacrificial lamb of Christian tradition. Caird states it baldly:

"Wherever the Old Testament says 'Lion', read 'Lamb"'. Wherever the Old Testament speaks of the victory of the Messiah or the overthrow of the enemies of God, we are to remember that the gospel recognizes no other way of achieving these ends than the way of the Cross (1984: 75).

However, it seemed to me that not only has the warrior lion been transformed by its juxtaposition with a lamb, the lamb has also picked up many of the traits of the warrior lion. For example, in Rev 6:16, the people of the world are said to hide from the "wrath of the lamb". In Rev 14:10, the enemies of the lamb receive double for their sins and "will be tormented with fire and sulphur in the presence of the holy angels and in the presence of the Lamb". There is a battle in Revelation 17 but the outcome is not in doubt, for the "Lamb will conquer them, for he is Lord of lords and King of kings" (Rev 17:14). In my reading of Revelation, the introduction of the messianic warrior lion has significantly disturbed John's story of the lamb. As Resseguie has more recently said, "the Lamb, though not in nature a strong animal, is a being of incontrovertible might in this book" (1998: 129).

Indeed, there is a line of interpretation that draws a contrast between the all-powerful lamb of Revelation and the lamb "who takes away the sin of the world" in John 1:29. Thus Dodd cites 1 Enoch 90 and Test. Joseph 19:8 and concludes that "we have here a prototype of the militant seven-horned "Lamb" of the Apocalypse of John" (1968: 232). Barrett looks to passages like Exodus 12, Isaiah 53, and Leviticus 16 as possible backgrounds for the lamb of John 1:29, but discounts Test. Joseph 19:8 since it "recalls the conquering lamb of Revelation . . . rather than the present passage" (1978: 147). And Raymond Brown concludes his discussion of John 1:29 with the words, "Thus we suggest that John the Baptist hailed Jesus as the lamb of Jewish apocalyptic expectation who was raised up by God to destroy evil in the world, a picture not too far from that of Rev xvii 14" (1966: 60). These might be considered overstatements but they point to the fact that John's presentation of the lamb has many "lion-like" features. It is by no means obvious that we are talking about the gentle lamb who takes away the sins of the world.

\subsection{The new Jerusalem}

Along with a succession of scholars, such as Vanhoye and Vogelgesang, I was impressed by the structural parallels between Ezekiel and Revelation, culminating in the extensive 
similarities between John's vision of the New Jerusalem and Ezekiel's vision of a restored temple.

\begin{tabular}{|l|l|}
\hline Ezekiel & Revelation \\
\hline $37: 10-$ Revival of dry bones & First resurrection (20:5) \\
\hline $37: 21-$ Reunited kingdom & Saints rule for 1,000 years (20:4) \\
\hline $38: 2-$ Gog of Magog battle & Gog and Magog battle (20:8) \\
\hline $39: 4-$ Gorging of the birds & Gorging of the birds (19:21) \\
\hline $40: 2-$ Taken to high mountain & Taken to high mountain (21:10) \\
\hline $40: 5-$ Temple is measured & City is measured (21:15) \\
\hline $43: 2-$ Temple full of God's glory & City full of God's glory (21:23) \\
\hline $47: 12 \mathrm{a}-$ River of life & River of life (22:1) \\
\hline $47: 12 b-$ Trees with healing leaves & Tree with healing leaves (22:2) \\
\hline
\end{tabular}

However, the climactic moment of John's vision is the declaration that there is no temple in the New Jerusalem because its temple is the "Lord God the Almighty and the Lamb" (21:22). It would appear that John wishes his readers to think of Ezekiel's vision of a restored temple only to confront them with a negation; the new Jerusalem does not have a temple. This is not simply fulfilment but a radical reinterpretation of Ezekiel's vision. As Vogelgesang says:

John made detailed use of Ezekiel 40-48 in constructing the new Jerusalem vision. Yet a greater contrast with that vision, where seven of nine chapters describe the temple, its ordinances and its priests, and the glory of God dwelling therein, cannot be imagined (1985: 77).

\subsection{Forms of imitation}

In Thomas Greene's analysis of imitation in Renaissance poetry, he speaks of reproductive, eclectic, heuristic and dialectical imitation. For reasons of space, we will omit discussion of his first two categories and focus on heuristic and dialectical imitation. According to Greene:

heuristic imitations come to us advertising their derivation from the subtexts they carry with them, but having done that, they proceed to distance themselves from the subtexts and force us to recognize the poetic distance traversed (1982: 40). 
Is this not a good description of John's use of Ezekiel 40-48? The parallels outlined above certainly "advertise" their derivation from Ezekiel but not to celebrate the majesty of Ezekiel's vision (which Greene would call "reproductive imitation") but to show us the "poetic distance traversed". In effect, John leads us into a trap. He convinces us that he is basing his vision of the New Jerusalem on Ezekiel, only to shock us with a temple gone missing. Traditional accounts of the use of Scripture in the New Testament, such as "prophecy and fulfilment", "type and anti-type", "allegory and midrash", are simply unable to capture this complexity.

Dialectical imitation is when the subtext is not negated but allowed a subversive influence on the new context. As Greene says, "The text makes a kind of implicit criticism of its subtexts, its authenticating models, but it also leaves itself open to criticism from [the text]... it had begun by invoking" (1982: 45). Despite Caird's argument that John intends to replace all the military associations of the "lion of Judah" by the sacrificial lamb of Christian tradition, this is not the impression the book makes on the majority of readers. The lion imagery is simply too powerful to be silenced and creates a "kind of struggle between texts and between eras which cannot easily be resolved" (1982: 45). John does not tell us that the messiah is a lamb and not a lion. Indeed, in Rev 5:5-6, John hears that the messiah is the "Lion of the tribe of Judah" and then sees "a Lamb standing as if it had been slaughtered". Now some commentators have suggested that what John sees here should reinterpret what he hears but this would contradict Rev 1:20, where he first sees the lampstands and then hears the interpretation. It is more likely that John is trying to tell us that the messiah is both a lion and a lamb and that the meaning is to be found in the resulting paradox and not through some forced resolution whereby lamb replaces lion.

\section{Recent discussion of John's use of Scripture}

In the last few years, John's use of Scripture, especially the book of Ezekiel, has been the subject of intense debate. Questions of continuity and discontinuity and the usefulness (or otherwise) of intertextuality have figured prominently in these studies.

\subsection{Ronald Farmer (1997)}

In his attempt to develop a process hermeneutic that overcomes what he calls "the present impasse" in biblical interpretation, Farmer devotes a chapter to the juxtaposition of the lion and lamb in Revelation 5. He notes that "if chapters 6-20 stood alone, it would be hard to see them as anything other than a cry for vengeance arising from anger, hatred, and envy" (1997: 156). However, these chapters are bracketed by the vision of God the Creator and Redeemer (Rev 4-5) and the One who makes all things new (Rev 21-22). Farmer's argument for a process hermeneutic is that the dominant theme of violence (or "lure" in process language) cannot easily be reconciled with the "undercurrent" of self-sacrifice:

Although the dominant "surface" imagery portrays God's power as coercive, allcontrolling, and unilateral, the analysis revealed a strong "undercurrent" working against the dominant imagery by means of basal lures suggesting that divine power be understood as persuasive, all-influencing, and relational (1997:160).

Farmer believes this can only be resolved by rejecting classical theism's view of an unchanging omnipotent God and looking to process theology. However, for our purposes, it is his evaluation of John's use of Scripture that is of interest: 
Whether John created this "undercurrent" intentionally or inadvertently, these basal lures nevertheless stand in tension with the deterministic worldview implied by the "surface" lures (1997:160).

In other words, John's juxtaposition of lion and lamb, ancient tradition and Christian tradition, cannot be resolved within traditional categories. They remain in tension with one another.

\subsection{Robert Royalty (1998)}

Royalty's book looks at the way John uses "wealth" imagery to construct his visions of the "one like a son of man" (Rev 1), the throne (Rev 4), Babylon (Rev 17) and the New Jerusalem (Rev 21-22). He claims that “John's free use of biblical texts to construct opulent visions of heaven and the New Jerusalem stands out within Second Temple Jewish literature" (1998: 79). For example, Ezekiel's description of the new temple is "remarkably plain" compared with the earlier descriptions of the tabernacle (Exod 28, 35, 39) or Solomon's temple (1 Kings 6-7). What John has done in his use of Ezekiel 40-48 is to restore "the missing elements of wealth and luxury" (1998: 77), which he derived primarily from displays of extravagance in popular Greco-Roman culture. Thus while Royalty agrees that we must examine the "hermeneutical complexity of Revelation's intertextuality" (1998: 39), he wishes to extend the scope of such intertextuality to include social and ideological factors. In other words, texts are not free-floating "agents of influence" but are embodied in social structures. To evoke "opulence" is not simply to evoke specific Old Testament texts but to evoke a variety of cultural phenomena. Indeed, he considers it "farfetched to imagine that John's free recombination and rewriting of scriptural texts has anything at all to do with the purpose of the original passages" (1998: 72). John's use of Scripture is not determined by the modernist concern for "proper" interpretation but his particular rhetorical purposes.

\subsection{Gregory Beale (1998)}

Much work has been done since Beale's study of 1984 and in this further monograph, Beale offers a critique of intertextuality and other "literary" developments. For example, he denies that John has created tensions in his work. The juxtaposition of lion and lamb is explained as "Semitic paratactic thinking which allowed the setting in close proximity of two different, and sometimes seemingly contradictory, ideas or a word, without the discomfort experienced by some twentieth-century readers" (1998: 47). In fact, the juxtaposition is solved reasonably well by the "already" and "not yet" presupposition of John's eschatology. Christ's past defeat of the enemy as a "lion" has begun in an ironic manner through death and suffering as a "lamb", but the future, consummate form of the enemy's defeat will be more straightforward: Christ will judge decisively and openly both his earthly and cosmic enemies, including Satan himself (1998: 46).

Beale also denies the notion that texts gain new meaning by being transposed into new settings. He acknowledges that some of John's interpretations might have been "surprising to an Old Testament audience" (1998: 128) but maintains that this constitutes a change in "significance" rather than a change in "meaning" (the distinction is from Hirsch). Thus while he acknowledges that John views the ancient texts through his Christian presuppositional lenses, he denies that this leads to a change in meaning, since (1) such presuppositional lenses are ultimately traceable to Christ's own approach to Scripture; (2) they ultimately derive from the Old Testament itself and so are not alien to its original intentions; and (3) they are true and hence do not distort the meaning of the Old Testament but clarify it (1998: 45). 


\subsection{Paul Decock (1999)}

After a survey of the most important aspects of John's use of Scripture, Decock turns to intertextuality "to create a space in which the tension between the old context and the new can be explored" (1999: 404). The problem with traditional approaches is that they imagine that the influence of Isaiah or Ezekiel comes to an end the moment John (or his secretary) puts down his pen (or stylus). However, "inter-textuality opens up a space to see the continuing co-operation of these surrounding texts in the production of meaning" (1999: 404). At the most basic level, John has formed a link with certain texts of Ezekiel so that from now on, they are read in juxtaposition with one another. Thus in a very real sense, "Ezekiel is as much a commentary on Revelation as Revelation is a comment on Ezekiel" (1999: 403-4). Decock recognises the post-modern roots of intertextuality but suggests that post-modern interpretation has more in common with pre-modern interpretation than is often realised:

John's pre-modern frame of mind inclined him to trust that the old texts would easily bend to the meaning of the new texts (the full revelation of God's plans), while the postmodern approach suspects - and rejoices - that the old contexts put up resistance and maintain a tension (1999: 406).

It is in fact "modernism", the rationalist belief that interpretation is best served by disinterested observers applying so-called scientific methods, which is the anachronism. Both pre-modern and post-modern interpretation believe in the fluidity of textual meaning. A text is a complex set of signs and there is always more than one way of configuring it. The difference between pre-modern and post-modern interpretation is that post-modern celebrates the lack of constraints, while pre-modern biblical interpretation operated within a believing community which imposed its own constraints. Decock list the following as the most significant (1999: 391):

- the rule of apostolic faith as a context for understanding

- the wholeness of Scripture as a comprehensive theological horizon

- the biblical and ecclesial witness to Christ as the "centre" of the biblical texts and their subsequent interpretation.

Decock would thus agree with Beale that "Christian presuppositions" guided John's interpretations and that these prevented him from lapsing into post-modern pluralism. However, this is not because John was constrained by the original meaning of the texts, which according to Decock, John was able to "bend" quite easily. The constraints come from belonging to a particular (Christian) reading community.

\subsection{Alison Jack (1999)}

Jack applies the post-modern concepts of marginalization and deconstruction to a reading of Revelation and a book by the Scottish writer, James Hogg. In her chapter on "Revelation reading the Hebrew Bible", she points out that both Jewish midrash and post-modern interpretation treat texts as truly open. She quotes Neusner (1987:103) as stating that:

Midrash... holds together two competing truths, first, the authority of Scripture, and second, that equally ineluctable freedom of interpretation implicit in the conviction that Scripture speaks now (Jack, 1999: 76)

Jack notes that many biblical scholars are using intertextuality for the traditional pursuit of sources and influence "but intertextuality assumes that the later text assimilates and adapts the earlier, which only achieves significance through what the later text makes of it" (1999: 89). She 
illustrates this with a fascinating study of Ezekiel's dry bones passage (Ezek 37) and the use made of it in Revelation 11 and the Qumran text, 4Q385. She concludes that "Ezekiel's message of comfort has been inverted, delayed and spiritualized into a heavenly reward for those who enter the world of suffering John creates" (1999: 124). The intertextual relationship between Ezekiel and Revelation does not result in both texts travelling through time together and continuing their mutual influence. Rather, the marginalized position of John and his readers has led him to offer a destabilizing reading of Ezekiel, which prevents future readers treating it as a stable text. Thus according to Jack, "Aspects of postmodern literary theory have yielded new insights into the intertextual relationship between Revelation, its context and its reading of the Hebrew Bible" (1999: 124).

\subsection{Sverre Bøe (2001)}

Bøe offers a study of Ezekiel 38-39 as Pre-text for Revelation 19,17-21 and 20,7-10. He does not believe that John alludes to the Gog of the land of Magog oracle because it offers a blueprint for what he wants to say. There are indeed many similarities, such as the names, the size of the army, a prior period of peace, God as the victor without human participation,

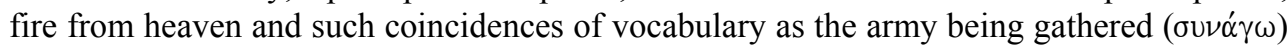
and going up to battle $(\alpha \nu \alpha \beta \alpha i \nu \omega)$. However, there are also significant differences, such as the introduction of Satan, Magog as a further antagonist rather than a place, their origin from the four corners of the earth rather than specific countries, and the fact that the battle is followed by the final judgement (2001: 342-3). Bøe discusses the suitability of terms like "prophecy and fulfilment" and "type and antitype" to describe this complex use of Scripture but concludes:

It is easier to use literary terms and describe the intertextual relationship between Ezekiel 38-39 and Rev 19,17-21 and 20,7-10 as one of transferring names, themes and motifs from one context to another, thus challenging the reader/listener to consider two contexts (2001: 367).

Bøe agrees that John used the new temple chapters (Ezek 40-48) in order to highlight the fact that the eschatological city does not have a temple (2001: 369) and claims that a similar strategy is at work in his use of the Gog material. It is a pity that Jack's work was not available to him, for it would have been interesting to know whether he thinks this "dialogical tension" is the vehicle for a stable (though dynamic) truth or whether it inevitably leads to deconstruction. My guess is that he would opt for the former.

\subsection{Pilchin Lee (2001)}

As we have seen, it is becoming a commonplace to highlight John's dependence on Ezek 40-48, only to surprise his readers with a negation. In Pilchin Lee's study of the Jewish background of Revelation 21-22, he says:

John's brief announcement of the absence of the New Temple building and "God and Jesus" as the new Temple must be intentional for the purpose of differentiating his view of the New Jerusalem from those of others in the Jewish tradition and it must be sensational in the contemporary apocalyptic milieu (2001: 296).

He notes that there may have been some precedent for this move in the way that the Qumran community sometimes identified itself with the temple, and in 3 Baruch's equation of temple and prayer. However, he states that the rebuilding of the temple "was the hottest issue among Jews living during the second Temple period" and so John's interpretation can 
only be seen as a "striking difference". How then do we account for it? According to Pilchin Lee, "John uses the early Jewish tradition creatively in terms of his Christological viewpoint" (2001: 296). That this is not simply a matter of "midrash" or "fulfilment" is shown by the fact that it is a "sensational" interpretation, that is, not one that naturally or logically springs from the text itself. Pilchin Lee does not try and locate this in a particular literary theory (such as intertextuality) but in John's "Christological viewpoint".

\subsection{David Mathewson (2003)}

Mathewson offers a detailed study of The Meaning and Function of the Old Testament in Revelation 21.1-22.5. Allusion to Isa 65:17 in Rev 21:1, 5 provides the overall framework of new creation, into which John incorporates the themes of new exodus, new Jerusalem, new covenant and new temple-priesthood, along with the themes of paradise restored and renewed, the adorned bride and the pilgrimage of the nations. Mathewson does not employ a specific theory of intertextuality but acknowledges that this "more interactive approach alerts us to the possibility of allowing for tension between Rev. 21.1-22.5 and its Old Testament intertexts" (2003: 15) and this informs some of his judgments. For example, "by integrating Ezek. 40-48 into a new context, it interacts with the voices of other prophetic texts which anticipate God's eschatological presence in the entire city... to form a complex of mutually interpreting texts" (2003: 122). Or more generally, "by sustained allusion to a constellation of Old Testament texts the author creates a plurality of semantic effects and associations in articulating his hope of eschatological salvation" (2003: 221).

However, for Mathewson, this "plurality of semantic effects" does not lead to unresolved tensions but is more like a symphony or work of art where the once disparate parts are now integrated into a new whole. This is well illustrated in his discussion of the theme of the pilgrimage of the nations in Rev 21:22-27. It has long puzzled commentators that John seems to envisage all of God's enemies being destroyed in the lake of fire ( $\operatorname{Rev} 19: 21)$, while also offering a universal vision of the nations bringing their glory into the new city (Rev 21:24). Furthermore, the new city is said to contain a tree of life which produces leaves "for the healing of the nations" (Rev 22:2). The problem is not so much the division between "lost" and "saved" but the "presence of universal statements of both judgment and salvation regarding the nations and kings throughout Revelation in seemingly conflicting fashion, both of which deserve a fair hearing" (2003: 172). It is the lack of a fair hearing that leads Mathewson to dismiss the identification of these "nations" with Christians (i.e. those "called out" of the nations) or with the nations mentioned earlier in the book (Rev 2:26; 11:2; $12: 5$ etc.), but now redeemed. He also challenges Bauckham's view that while one must do justice to the universal statements concerning judgment and salvation, the latter are to be afforded theological priority. Instead, Mathewson regards this juxtaposition of opposites as a rhetorical strategy to highlight the "comprehensive nature of God's judgment and salvation, and to demonstrate what is at stake" (2003: 175). It is not two pictures of the end that must somehow be reconciled but a rhetorical strategy of using absolute statements to starkly present the alternatives facing the readers. In this way, Mathewson claims that John does in fact offer a resolution to the apparently conflicting imagery.

\section{Conclusions}

As can be seen from this brief survey, there has been an enormous interest in John's use of Scripture, particularly the book of Ezekiel. Intertextuality has figured in the interpretations of Royalty, Decock, Jack, Bøe and Mathewson but is criticised by Beale. All acknowledge that some of John's interpretations would have been surprising to an Old Testament 
audience and some (Royalty, Jack) regard this as a subversion of the ancient texts. Others, such as Mathewson, argue that the "plurality of semantic effects" leads to a stable if complex vision of the eschatological end. I end with four observations.

\subsection{John's use of Ezekiel is surprising/sensational}

The fact that a temple does not figure in a Christian vision of the future is hardly surprising. After all, Jesus predicted the destruction of the temple (Mark 13:2) and Christians believed that "Christ had offered for all time a single sacrifice for sins" (Heb 10:12). What is surprising in the book of Revelation is that John makes so many references to Ezekiel 37 48 (Nestle-Aland $^{27}$ lists 30 ) only to offer a radically different vision. He was under no compulsion to use Ezekiel. The same lists in Nestle-Aland ${ }^{27}$ indicate that the rest of the New Testament only contains 19 references to Ezekiel 37-48. For some reason, John felt it was necessary to give the impression that he is following Ezekiel only to make radical changes. Beale's attempt to call these "changes of significance" rather than "changes of meaning" merely confuses the issue. How is exegesis served by stating that what Ezekiel "really" meant when he devoted "seven of nine chapters [to] describe the temple, its ordinances and its priests" (Vogelgesang, 1985: 77) was in fact a New Jerusalem without a temple? Mathewson makes the valid point that the notion of "dialogical tension" needs qualifying, since John undoubtedly sees his vision as the "true successor" of Ezekiel (and perhaps all of Scripture). However, I would suggest that the resolution he proposes also needs qualifying, for spinning plates, a musical performance and a work of art (the three metaphors with which he ends his book) all suggest a dynamic reality where the reader participates in the creation of meaning, rather than a fixed stable interpretation.

\subsection{John's lion and lamb juxtaposition remains a matter of debate}

From the above studies, only Farmer and Beale discuss the lion and lamb juxtaposition. Farmer supports the view that the two ideas (Jesus as warrior lion and Jesus as sacrificial lamb) are in tension with one another and suggests they can only be resolved through process theology. Beale denies there is any tension, stating that we should view them in temporal sequence: Jesus initial (ironic) victory was as a lamb but his final victory will be as an all-conquering lion. This is a departure from the Caird tradition, which was concerned to refute the view that "might is right" (i.e. Christ is to be obeyed because he is more powerful than Satan) by suggesting that lamb reinterprets lion. Beale does not seem to share this concern, stating that Christ's manifestation as a lamb was simply part of an initial ironic victory but in the future, "the enemy's defeat will be more straightforward" (1998: 46).

Among recent commentators, Aune accepts the view that Jesus is both warrior lion and sacrificial lamb, noting that while "this 'irony of kingship through crucifixion' is certainly a central theological emphasis here in Rev 5, it is a marginal conception elsewhere in the book" (1997: 353). Murphy says the "central issue is whether the warlike traits of a lion are replaced by the meekness of the Lamb or whether the messiah retains warlike qualities" (1998: 193). His answer is that neither are replaced: "Christ won his victory over Satan and made possible the victory of Christians through his suffering and death. This is non-violent. But he will also exercise force against the partisans of evil (chapter 19) and will punish them as they deserve" (ibid). Resseguie supports the Caird tradition by positing a hearing/seeing strategy that runs throughout the book. Thus "John overturns conventional expectations that the Messiah will subjugate Israel's enemies by conquest and might, and replaces that expectation with a new definition of conquest and might - a slaughtered Lamb" (1998: 134). On the other hand, Koester argues that both images point to the same 
reality: "What John hears about the Lion recalls promises from the Old Testament, and what he sees in the Lamb reflects the crucifixion of Christ" (2001: 78). The promise of a powerful ruler is not "rejected but fulfilled through the slaughtered yet living Lamb, who is not a hapless victim but a figure of royal strength" (ibid). Thus the issue of the lion and the lamb continues to be a matter of debate (see further Moyise, 2001).

4.3 Intertextuality is a useful concept for studying John's use of Scripture

Theories of intertextuality do not explain John's interpretations. Rather, they provide a conceptual background for understanding how such interpretations might be possible. On the Enlightenment understanding that a text has one single meaning (the author's intention), reinterpreting texts in the light of Christological presuppositions can only be seen as a distortion, because it is clearly not what Ezekiel had in mind. But on the pre-modern (and post-modern) view that texts can change their meaning (or "bend" as Decock puts it) when relocated into new contexts, Christological interpretation is not only understandable but inevitable. Though the scholars discussed above have used different forms of intertextuality and differ in their conclusions about John's use of Scripture, it has proved to be a fruitful avenue of research.

4.4 Theological explanations need to be related to literary explanations

Pilchin Lee describes John's interpretations as "sensational" and explains them by reference to John's "Christological viewpoint". Beale acknowledges that some of John's interpretations might have been "surprising" to an Old Testament audience but claims that they are fully understandable given John's Christian presuppositions. However, what is left unclear in these "theological" explanations is whether this is to be regarded as a unique Christian phenomenon or a particular example of a property possessed by all texts (as intertextuality claims). In other words, was John able to do what he did with Ezekiel because divine inspiration miraculously "set aside" the natural meaning of the text (Gog of the land of Magog; a bricks and mortar temple), or because it utilised the fact that all texts have the property of altering their meaning when transposed into new contexts? Whatever one's understanding of inspiration, the result was a text. Understanding what happens to texts when they are taken out of their old context(s) and transposed into new ones is a necessary part of understanding the collection of books that make up the Bible.

\section{BIBLIOGRAPHY}

Aune, D 1997. Revelation 1-5. WBC 52A; Dallas: Word Books.

Barrett, CK 1978. The Gospel According to St John. London: SPCK.

Bauckham, R 1993. The Climax of Prophecy: Studies in the Book of Revelation. Edinburgh: $\mathrm{T} \& \mathrm{~T}$ Clark.

Beale, GK 1984. The Use of the Daniel in Jewish Apocalyptic Literature and in the Revelation of St John. Lanham: University Press of America. 1998. John's Use of the Old Testament in Revelation. JSNTSup 166; Sheffield: Sheffield Academic Press.

Bøe, Sverre 2001. Gog and Magog. Ezekiel 38-39 as Pre-text for Revelation 19,17-21 and 20,7-10. Tübingen: Mohr Siebeck.

Brown, RE 1966. The Gospel According to John. Garden City, NY: Doubleday. 
Caird, GB 1984. The Revelation of St John the Divine. London: A \& C Black.

Decock, PB 1999. The Scriptures in the Book of Revelation. Neotestamentica 33, pp.373410.

Dodd, CH 1968. The Interpretation of the Fourth Gospel. Cambridge: Cambridge University Press.

Farmer, R 1997. Beyond the Impasse. The Promise of a Process Hermeneutic. Macon: Mercer University Press.

Fekkes, J 1994. Isaiah and Prophetic Traditions in the Book of Revelation. JSNTSup 93; Sheffield: Sheffield Academic Press.

Greene, TM 1982. The Light in Troy: Imitation and Discovery in Renaissance Poetry. New haven: Yale University Press.

Hollander, J 1981. The Figure of Echo: A Mode of Allusion in Milton and After. Berkeley: University of California Press.

Jack, A 1999. Texts Reading Texts, Sacred and Secular. JSNTSup 179; Sheffield Academic Press.

Koester, CR 2001. Revelation and the End of all Things. Grand Rapids: Eerdmans.

Kristeva, J 1986 [1969]. Word, Dialogue and Novel. (In T Moi (ed.), The Kristeva Reader. New York: Columbia University Press).

Mathewson, D 2003. A New Heaven and a New Earth. The Meaning and Function of the Old Testament in Revelation 21.1-22.5. JSNTSup 238; Sheffield Academic Press.

Moyise, S 1993. Intertextuality and the book of Revelation. Expository Times 104, pp.295-8. 1995. The Old Testament in the Book of Revelation. JSNTSup 115; Sheffield: Sheffield Academic Press.

2001. Does the Lion lie down with the Lamb? (in S.Moyise (ed.). Studies in the Book of Revelation. Edinburgh: T \& T Clark).

Murphy, FJ 1998. Fallen is Babylon. The Revelation to John. Harrisburg: Trinity Press International.

Neusner, J 1987. What is Midrash? Philadelphia: Fortress Press.

Pilchin, Lee 2001. The New Jerusalem in the Book of Revelation: A Study of Revelation 2122 in the Light of its background in Jewish Tradition. Tübingen: Mohr Siebeck.

Resseguie, JL 1998. Revelation Unsealed. A Narrative Critical Approach to John's Apocalypse. Leiden: Brill.

Royalty, RM 1998. The Streets of Heaven. The Ideology of Wealth in the Apocalypse of John. Macon: Mercer University Press.

Vanhoye, A 1962. L'utilisation du livre d'Ezéchiel dans l'Apocalypse. Biblica 43, pp.436-77.

Vogelgesang, JM 1985. The Interpretation of Ezekiel in the Book of Revelation. Dissertation, Harvard University, Cambridge MA.

Vos, LA 1965. The Synoptic Traditions in the Apocalypse. Kampen: Kok. 